\title{
Preclinical assessment of intravitreal ramucirumab: in vitro and in vivo safety profile
}

\author{
Jarbas Emílio de Moraes Neto ${ }^{1 \dagger}$, Felipe Pereira ${ }^{1 *+}$ (D), Raquel Leão Neves ${ }^{2}$, Nilana Meza Tenório de Barros², \\ Cristiane Damas Gil ${ }^{3}$, Arthur Gustavo Fernandes ${ }^{1}$, Sung Eun Song Watanabe ${ }^{1}$, Carsten Helmut Meyer ${ }^{1}$, \\ Michel Eid Farah ${ }^{1}$ and Eduardo Buchele Rodrigues ${ }^{1,4}$
}

\begin{abstract}
Background: Anti-angiogenic drugs remain the mainstay therapy for several vascular retinal pathologies. The repurposing of approved anti-angiogenic drugs for use in ophthalmology can increase therapeutic options and reduce costs. The purpose of this study was to investigate the ocular safety profile of intravitreal (IVT) ramucirumab, an approved anti-vascular endothelial growth factor molecule for systemic treatment, using cell culture and animal models.

Methods: The cytotoxicity of ramucirumab at different concentrations was evaluated in human retinal pigment epithelial cells (ARPE-19) using the MTT assay. In addition, 250 or $500 \mu \mathrm{g}$ of ramucirumab or vehicle was injected in the eye of 16 chinchilla rabbits. The eyes were evaluated by ophthalmoscopy, electroretinography, spectral-domain optical coherence tomography (SD-OCT) and by light and transmission electron microscopy.

Results: Electroretinography or SD-OCT did not detect functional or morphological alterations at $24 \mathrm{~h}$ or one week after injection. Light and transmission electron microscopy confirmed the absence of major signs of toxicity, although we found a statistically significant reduction in ganglion cell number between the controls and the eyes that received $500 \mu \mathrm{g}$ of ramucirumab after 7 days. Compared to lower concentrations, $500 \mu \mathrm{g}$ of ramucirumab caused reduction in cell viability and changes in morphology in ARPE-19 cells. Compared to the baseline, ocular and serum osmolarity showed no difference after IVT injection at all timepoints.

Conclusion: In conclusion, IVT injection of ramucirumab in rabbits is safe and does not cause functional damage to the retina. At the lower dose tested in vivo $(250 \mu \mathrm{g})$, the morphology and ultrastructural anatomy were normal at $24 \mathrm{~h}$ and 1 week after the injection. However, the $500 \mu \mathrm{g}$ dose can cause a decrease in ganglion cell number seven days after the injection.
\end{abstract}

Keywords: Anti-VEGF, Ramucirumab, Safety, Experimental, Intravitreal injection

\footnotetext{
*Correspondence: felipe_pera@hotmail.com

†Jarbas Emílio de Moraes Neto and Felipe Pereira contributed equally to this article

${ }^{1}$ Departamento de Oftalmologia E Ciências Visuais, Escola Paulista de Medicina, Universidade Federal de São Paulo (UNIFESP), São Paulo, SP 04023-062, Brazil

Full list of author information is available at the end of the article
}

\section{Background}

Abnormal angiogenesis is the core pathogenesis of several ocular blindness diseases such as diabetic retinopathy and age-related macular degeneration (AMD) [1] The interaction between pro-angiogenic factors and their receptors is tightly regulated with several positive and negative feedback circuits [2]. Vascular endothelial growth factor (VEGF) and its receptors (VEGFRs) constitute the main force driving abnormal and persistent angiogenesis [3].

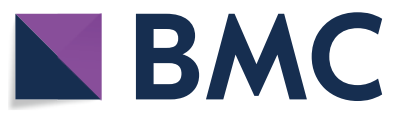

(c) The Author(s) 2020. This article is licensed under a Creative Commons Attribution 4.0 International License, which permits use, sharing, adaptation, distribution and reproduction in any medium or format, as long as you give appropriate credit to the original author(s) and the source, provide a link to the Creative Commons licence, and indicate if changes were made. The images or other third party material in this article are included in the article's Creative Commons licence, unless indicated otherwise in a credit line to the material. If material is not included in the article's Creative Commons licence and your intended use is not permitted by statutory regulation or exceeds the permitted use, you will need to obtain permission directly from the copyright holder. To view a copy of this licence, visit http://creativeco mmons.org/licenses/by/4.0/. The Creative Commons Public Domain Dedication waiver (http://creativecommons.org/publicdomain/ zero/1.0/) applies to the data made available in this article, unless otherwise stated in a credit line to the data. 
Vascular endothelial growth factor receptor 2 (VEGFR2 ) is one of the main regulators of angiogenesis, during which the receptor is overexpressed on the surface of endothelial cells. The main pro-angiogenic factor is VEGFA, but VEGFC and VEGFD can also activate the VEGFR signaling pathway $[4,5]$. The mainstay treatment for ocular neovascular diseases consists in blocking different pro-angiogenic ligands. However, since different ligands can act on the same receptor, the direct inhibition of VEGFR-2 over the inhibition of its ligands may be a more suitable therapeutic target [2].

Ramucirumab (Fig. 1a) is a recombinant, human monoclonal antibody, produced in a transfected NS0 mouse myeloma cell line, that binds specifically to VEGFR-2 and blocks VEGF-A, VEGF-C, and VEGF-D binding [6]. The fragment crystallizable $(\mathrm{Fc})$ portion of ramucirumab is not required for its action [7]. Ramucirumab binds to VEGFR-2 with high affinity $(\mathrm{Kd}=50 \mathrm{pM})$, similar to the dissociation coefficient of bevacizumab $(\mathrm{Kd}=58 \mathrm{pM})$ and ranibizumab $(\mathrm{Kd}=46 \mathrm{pM})$. The molecular weight is $146 \mathrm{kDa}$, which is similar to bevacizumab (149 kDa) and heavier than ranibizumab $(48 \mathrm{kDa})$ and aflibercept (115 kDa) [8].

Preclinical cellular and animal models have demonstrated that the result of ramucirumab binding to its target is the inhibition of VEGF-induced VEGFR-2 activation and inhibition of VEGF-stimulated cell migration and proliferation $[6,9]$.

This drug is provided as an intravenous solution $\left(\right.$ Cyramza $^{\circledR}$, Eli Lilly, Indianapolis, USA) in two formulations, $100 \mathrm{mg} / 10 \mathrm{~mL}$ and $500 \mathrm{mg} / 50 \mathrm{~mL}$ and was approved by the US Food and Drug Administration in 2014 to treat advanced gastric and gastroesophageal cancer.

Since ramucirumab inhibits angiogenesis by specifically targeting VEGFR-2 (Fig. 1b), its repurposing to treat vascular eye diseases through intravitreal (IVT) injections is tempting and finds a parallel in the use of bevacizumab to treat neovascular AMD nearly 15 years ago. Although the systemic use of ramucirumab has not shown higher toxicity than other anti-angiogenic agents, to our knowledge, the safety of intraocular injection of ramucirumab has not yet been tested. The purpose of this study was to investigate for the first time the intraocular safety of ramucirumab using human retinal pigment epithelial (RPE) cells and IVT injection in an animal model.

\section{Methods}

This was an experimental study and all the procedures were performed following the guidelines of the Association of Research in Vision and Ophthalmology (ARVO). Approval was obtained from Institutional Animal Care and Use Committee (IACUC) prior to the initiation of the study, under the number 6610041117.

\section{Cell viability assay}

Human RPE cells (ARPE-19; ATCC CRL-2302) were used to assess the in vitro toxicity of ramucirumab using the MTT (thiazolyl blue tetrazolium bromide) colorimetric assay as previously described [10]. Briefly, the cells were grown in DMEM/F12 containing $10 \mathrm{U} / \mathrm{mL}$ penicillin and $10 \mu \mathrm{g} / \mathrm{mL}$ streptomycin and

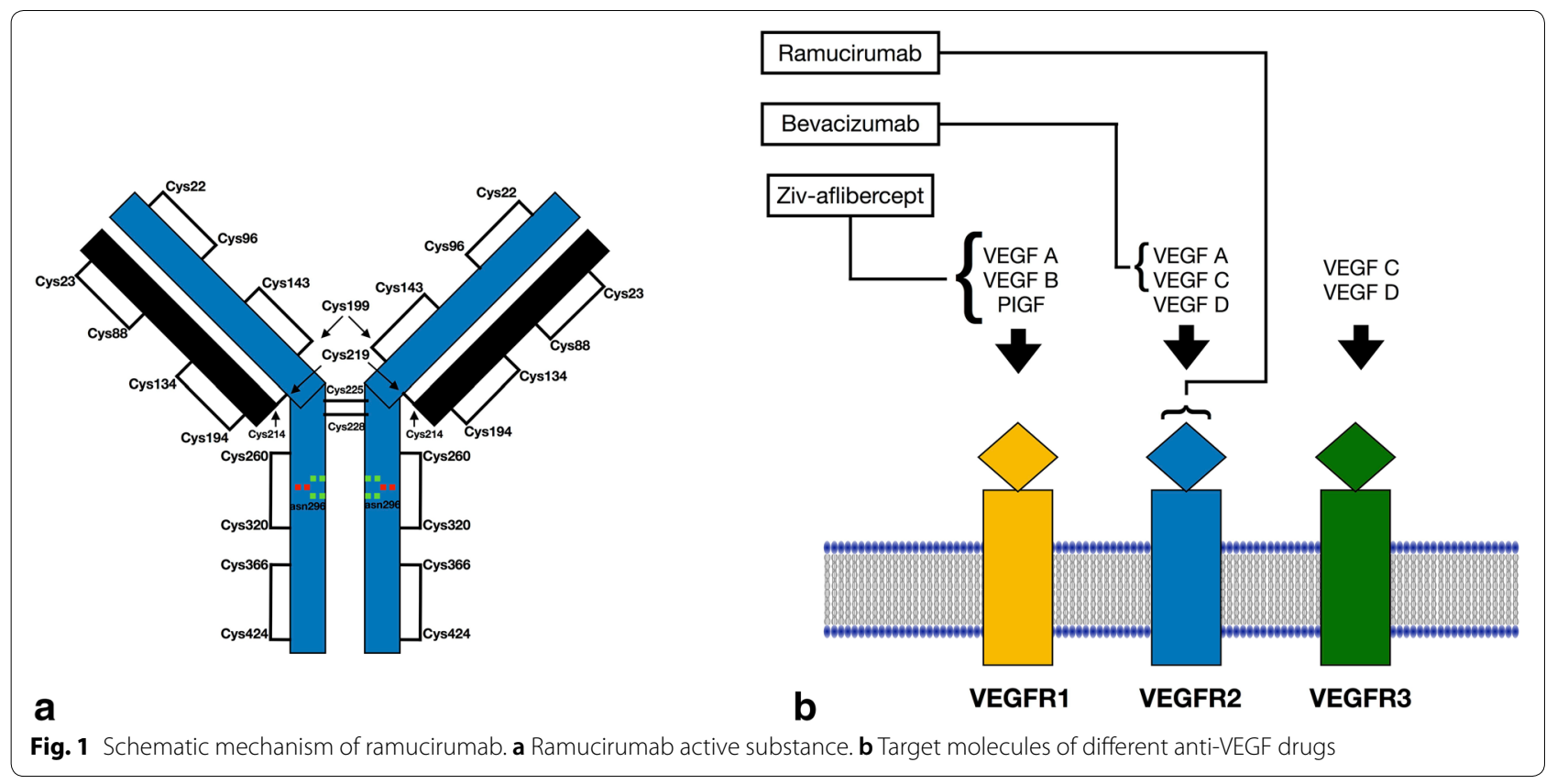


supplemented with $10 \%$ fetal bovine serum (Gibco/ Thermo Fisher Scientific Inc.-Waltham, MA, USA). Cells were seeded $\left(5 \times 10^{3}\right.$ cells per well $)$ and incubated for $24 \mathrm{~h}$ in a humidified incubator containing $5 \% \mathrm{CO}_{2}$ at $37^{\circ} \mathrm{C}$.

Cells were treated with increasing concentrations of ramucirumab (from 10 to $500 \mu \mathrm{g} /$ well) for $2 \mathrm{~h}$ and dimethyl sulfoxide (DMSO) was used as a positive control. Absorbance at $570 \mathrm{~nm}$ was measured and the value obtained with culture medium was used as blank. The experiments were performed in triplicate and repeated three times.

\section{In vivo experiment design}

IVT injections of ramucirumab were performed in 16 male chinchilla rabbits weighing from 1.8 to $2.5 \mathrm{~kg}$. The animals were equally divided into two groups (A and B). The right eye of each animal received $0.05 \mathrm{~mL}$ of IVT ramucirumab, corresponding to $500 \mu \mathrm{g}$ of the drug (group A), or $0.025 \mathrm{~mL}$, corresponding to $250 \mu \mathrm{g}$ of the drug (group B). The left eye (control group) received $0.05 \mathrm{~mL}$ or $0.025 \mathrm{~mL}$ of balanced saline solution (BSS) (300 mOsm). Fundus photography, electroretinography (ERG), spectral-domain optical coherence tomography (SD-OCT) and serum/aqueous humor analysis were performed at baseline and $24 \mathrm{~h}$ (eight rabbits) or seven days (eight rabbits) after the injection. After the followup examination the animals were euthanized, and the eyes were collected for histological preparation.

\section{Functional analysis by electroretinography}

ERG was performed at baseline and $24 \mathrm{~h}$ or seven days after the intravitreal injection. After complete pupil dilation with tropicamide $1 \%$ and cornea anesthesia with proparacaine eye drops, unipolar electrodes (ERG jet ${ }^{\circledR}$, Universe SA, La Chaux-de-Fons, Switzerland) were properly placed on each cornea together with methylcellulose 2\% (Ophthalmos, São Paulo, Brazil).

After $30 \mathrm{~min}$ of dark adaptation, the animals were assessed by the RETI-port gamma plus ${ }^{\circledR}$ (Roland Consult, Brandenburg an der Havel, Germany) according to four types of response: rod response, combined response, cone response and flicker. A 50\% decrease in the postinjection response compared to baseline was considered significant. Statistical analyses were performed using Stata/SE Statistical Software, version 14.0, 2015 (StataCorp, College Station, TX, USA). Data are presented as median (range) and the Wilcoxon signed-rank test was used to compare baseline and follow-up measurements. $p$ values $\leq 0.05$ were considered statistically significant.

\section{Fundus photography and spectral-domain optical coherence tomography}

We performed anterior segment biomicroscopy, fundus photography (Zeiss Visucam $524^{\circledR}$, Carl Zeiss, Jena, Germany) and SD-OCT (Spectralis ${ }^{\circledR}$, Heidelberg Engineering, Heidelberg, Germany) at baseline and $24 \mathrm{~h}$ or seven days after intravitreal injection.

\section{Serum and aqueous humor osmolarity}

Peripheral blood and aqueous humor tap from both eyes were collected using an insulin syringe with a 27 -gauge needle. After collection, the samples were frozen at $-80{ }^{\circ} \mathrm{C}$ and later assessed using an osmometer. The Wilcoxon signed-rank test was used to compare baseline and follow-up measurements of blood and aqueous humor osmolarity.

\section{Light microscopy and transmission electron microscopy}

Eyes were processed for light microscopy (LM) and transmission electron microscopy (TEM) as previously described [11]. Briefly, for LM, eyes were fixed in $4 \%$ paraformaldehyde at $4{ }^{\circ} \mathrm{C}$. Following embedding in paraffin, the eyes were sectioned, stained with hematoxylin and eosin (H\&E) and imaged using an Axioskop 2-Mot Plus Zeiss microscope (Carl Zeiss, Jena, Germany). The ganglion cells were manually quantified using a $20 \times$ objective in three semi-serial sections of retina for each eye. Values are expressed as the mean \pm SEM of the number of cells per $\mathrm{mm}^{2}$.

For ultrastructural analysis, eyes were fixed in $4 \%$ paraformaldehyde and $0.5 \%$ glutaraldehyde in $0.1 \%$ sodium cacodylate buffer ( $\mathrm{pH}$ 7.4) for $24 \mathrm{~h}$ at $4{ }^{\circ} \mathrm{C}$. After washing and dehydration in methanol, samples were embedded in LR Gold (Sigma-Aldrich, Steinheim, Germany). Imaging was performed using a ZEISS EM900 electron microscope (Carl Zeiss, Jena, Germany).

\section{Results}

\section{Cell viability assay}

To evaluate the cytotoxic effects of ramucirumab, we initially performed an in vitro cell viability assays using ARPE-19 cells treated with 10, 25, 50, 100, 200, 250 and $500 \mu \mathrm{g} /$ well of drug for $2 \mathrm{~h}$. Cell viability was assessed by the MTT colorimetric assay and the results indicated that concentrations up to $250 \mu \mathrm{g} /$ well did not affect the cells. However, at $500 \mu \mathrm{g} /$ well, cell viability was reduced, and the cells had slight changes in morphology (Fig. 2).

\section{Functional analysis by electroretinography}

There was no difference in retinal response between eyes injected with ramucirumab and eyes injected with 


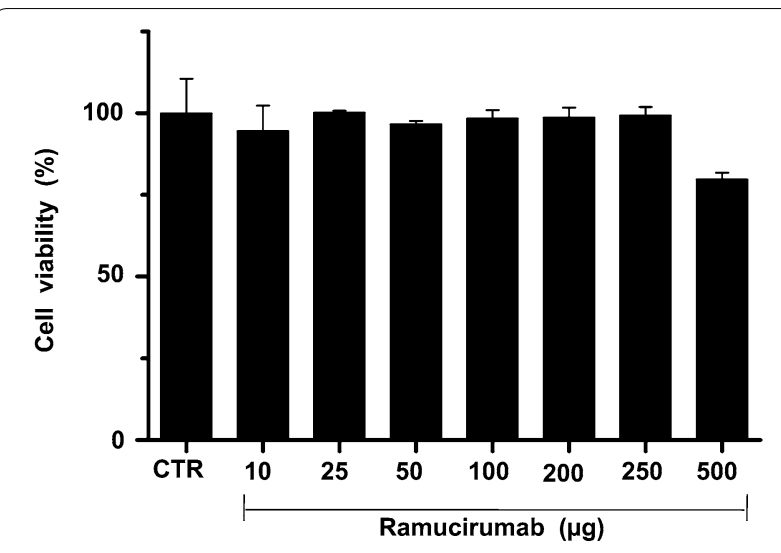

Fig. 2 Effects of ramucirumab on ARPE-19 cells. Cells were incubated in the presence of ramucirumab at 10,25, 50, 100,200, 250 and $500 \mu \mathrm{g} /$ well for $2 \mathrm{~h}$. The MTT assay was performed to evaluate cell viability. The experiments were performed in triplicate and repeated three times

BSS in all protocols used and at all timepoints of the study (Fig. 3). Table 1 specifies the results of each ERG protocol used for all groups.
Fundus photography and spectral-domain optical coherence tomography

In all eyes studied, fundus images did not show any significant alterations, and SD-OCT displayed normal anatomical architecture of all retinal layers at all assessed times (Fig. 4).

\section{Serum and aqueous humor osmolarity}

Table 2 shows osmolarity values (presented as median) from serum and aqueous humor collected before and after IVT injection of ramucirumab or BSS. Compared to the baseline of each eye, there was no difference in the osmolarity of serum and aqueous humor. Due to technical issues the serum samples from day 7 of follow-up from lower dose group $(250 \mu \mathrm{g})$ were not evaluated.

\section{Light microscopy and transmission electron microscopy}

The morphology assessed by H\&E demonstrated similar findings between both doses of ramucirumab and the controls. There was no evidence of recruitment of inflammatory cells, and the retinal layers were preserved. Some vacuolization in the superficial layers was present after $24 \mathrm{~h}$ and showed less intensity after 7 days in all groups, including the controls. The retinal thickness measured

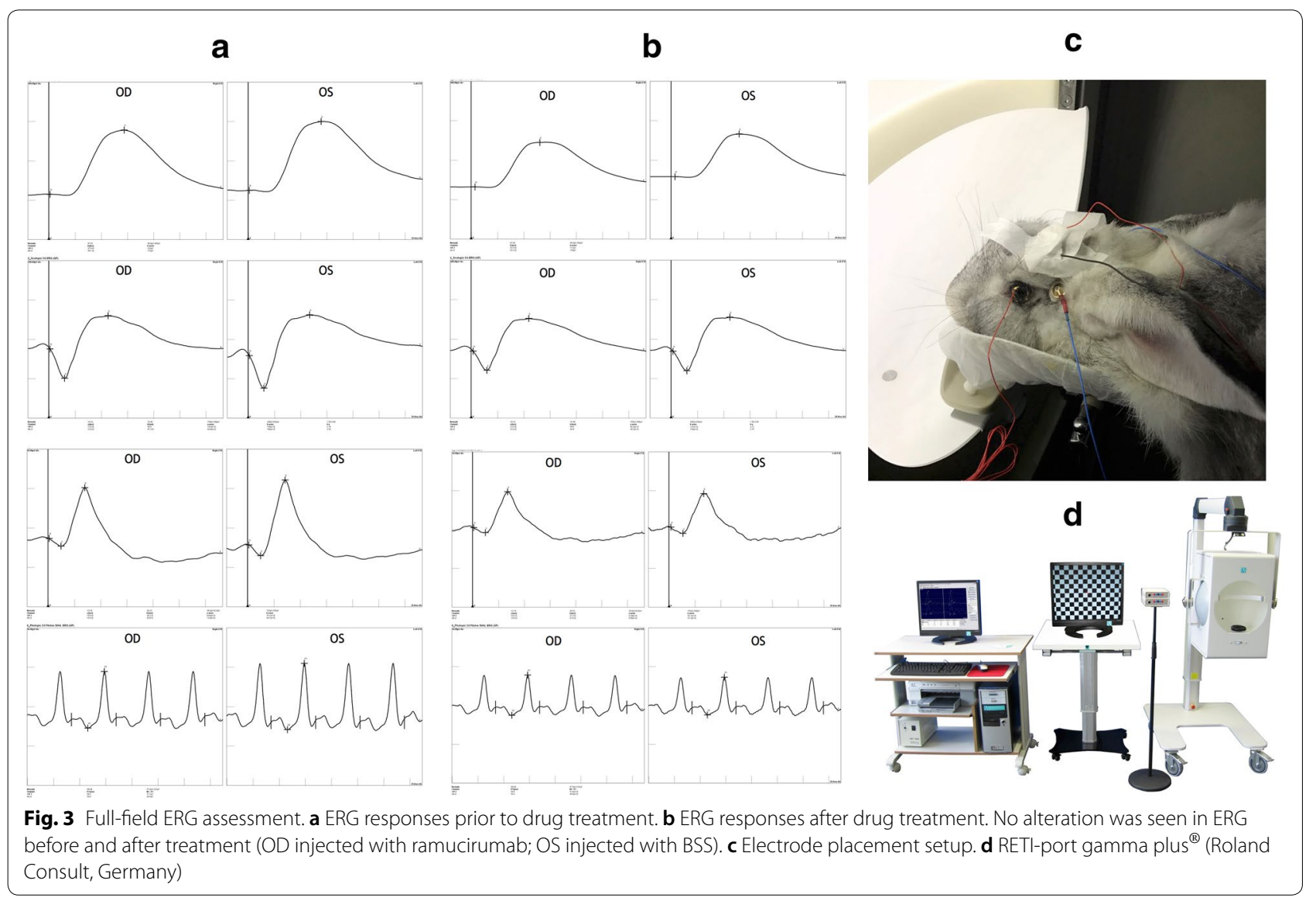




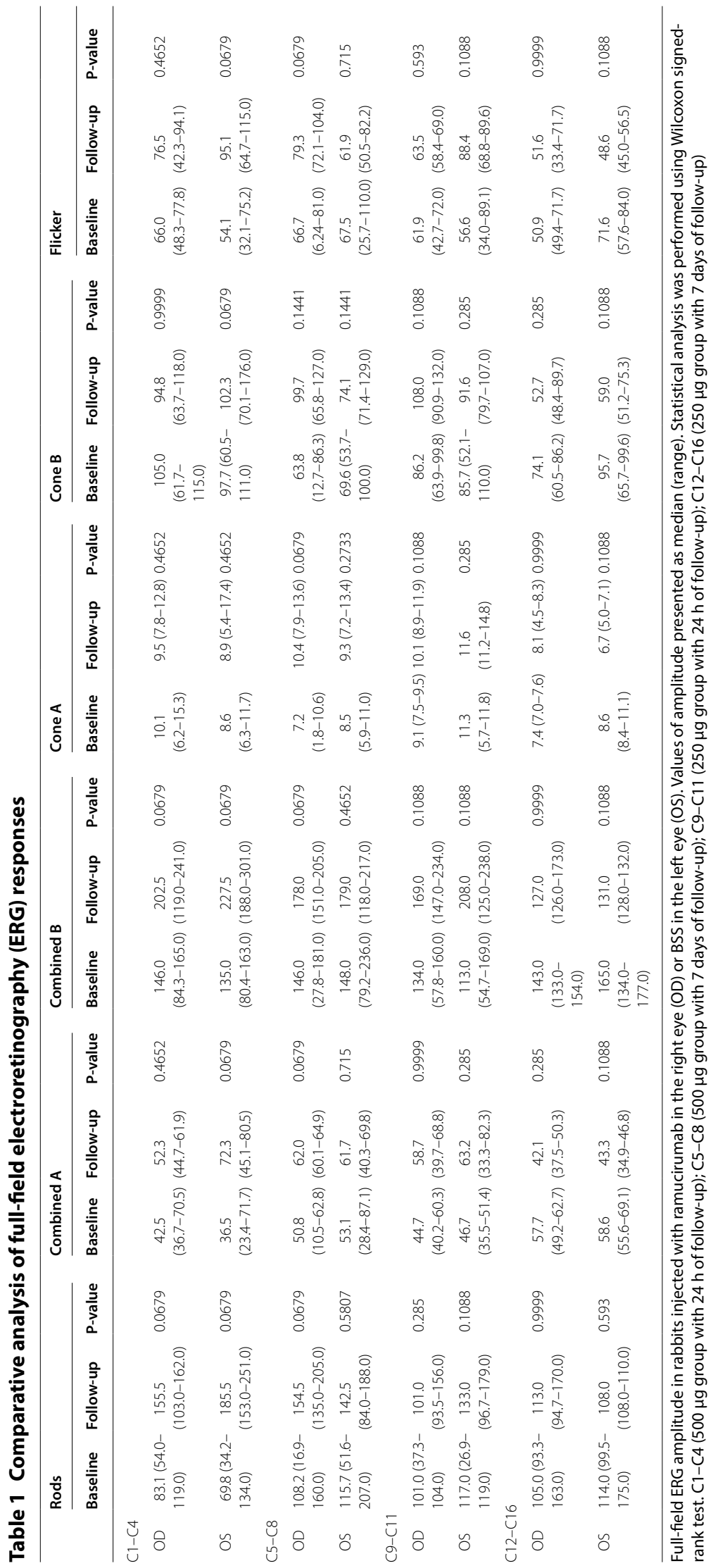




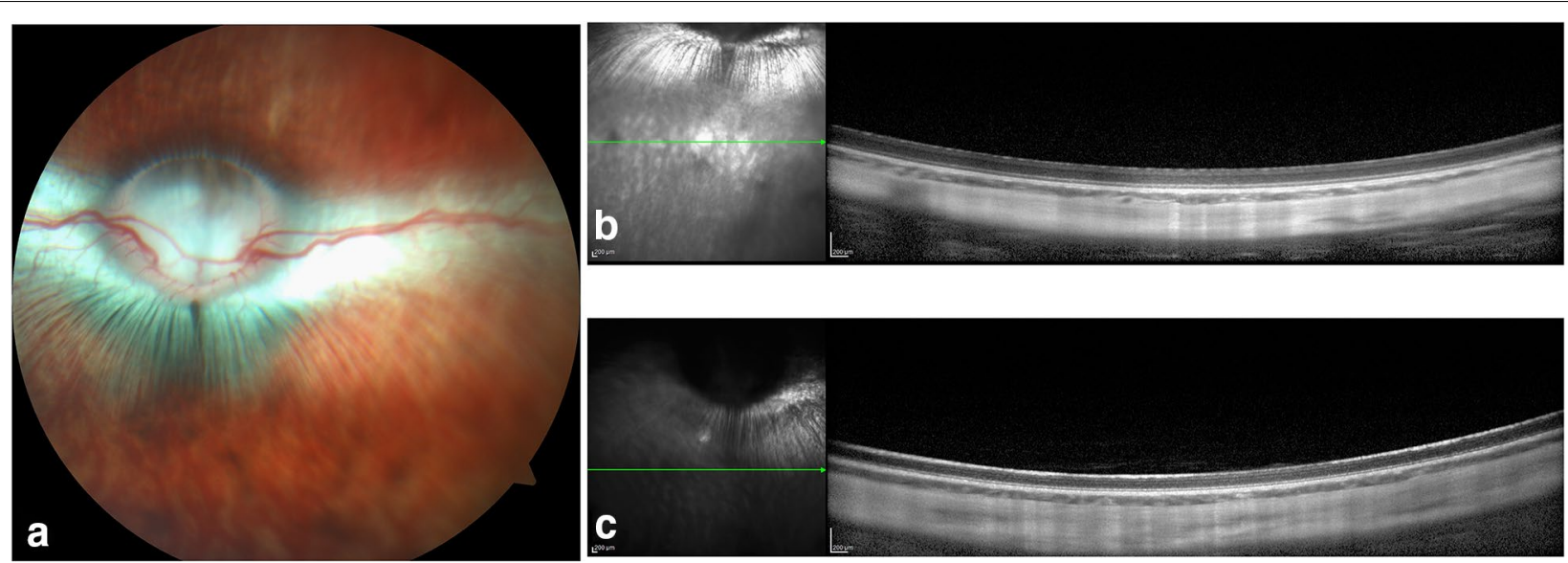

Fig. 4 Morphological assessment after intravitreal injection of ramucirumab. a Fundus color imaging after intravitreal injections. b OCT prior to intravitreal injections. c OCT after intravitreal injections. All images correspond to the $500 \mu \mathrm{g}$ group

Table 2 Serum and aqueous humor osmolarity

\begin{tabular}{|c|c|c|c|c|c|c|}
\hline & \multicolumn{3}{|l|}{ Blood osmolarity } & \multicolumn{3}{|c|}{ Aqueous humor osmolarity } \\
\hline & Baseline & Follow-up & P value & Baseline & Follow-up & $P$ value \\
\hline $\mathrm{Cl}-\mathrm{C} 4-24 \mathrm{~h}$ & $338.5(270.0-358.0)$ & $337.0(335.0-357.0)$ & 0.9999 & $300.0(300.0-300.0)$ & $331.0(320.0-342.0)$ & 0.9999 \\
\hline C5-C9-7 days & $331.0(324.0-355.0)$ & $324.5(324.0-325.0)$ & 0.1797 & $332.0(319.0-339.0)$ & $315.5(246.0-329.0)$ & 0.0679 \\
\hline C9-C11-24h & $307.5(281-334.0)$ & $309.0(260.0-322.0)$ & 0.1797 & $319.0(212.0-323.0)$ & $331.0(323.0-381.0)$ & 0.1088 \\
\hline C12-C16-7 days & NA & NA & NA & $323.0(309.0-338.0)$ & $316.0(305.0-435.0)$ & 0.9999 \\
\hline
\end{tabular}

Serum and aqueous humor osmolarity in rabbits injected with ramucirumab in the right eye at baseline and follow-up. Values of osmolarity are presented as median (range). Statistical analysis was performed using Wilcoxon signed-rank test. C1-C4 (500 $\mu$ g group with $24 \mathrm{~h}$ of follow-up); C5-C8 (500 $\mu \mathrm{g}$ group with 7 days of follow-up); C9-C11 (250 $\mathrm{gg}$ group with $24 \mathrm{~h}$ of follow-up); C12-C16 (250 $\mu \mathrm{g}$ group with 7 days of follow-up-blood osmolarity not available). NA not available due to technical problems

displayed no difference between eyes injected with ramucirumab and BSS (Fig. 5). Furthermore, we determined the number of ganglion cells in each eye. Ramucirumab at $500 \mu \mathrm{g}$ caused a significant loss in ganglion cells compared with BSS $(59.0 \pm 5.0$ vs $30.0 \pm 2.5, p<0.01$ in the t-test $\left[\right.$ mean \pm SEM. of the number of cells $/ \mathrm{mm}^{2} ; \mathrm{n}=4$ / group]) (Fig. 6).

TEM confirmed the LM findings. At $24 \mathrm{~h}$ and seven days, retinas showed a normal appearance and integrity of the nerve fiber and inner and outer nuclear layers, without signs of apoptosis, while a small number of vacuoles were seen in the inner and outer plexiform layers (Fig. 7).

\section{Discussion}

Inhibition of VEGFR-2 by ramucirumab in animal models and human trials has demonstrated significant antitumor activity in a variety of malignancies, both as monotherapy and in combination with other drugs $[8,12$, 13]. However, no previous study has evaluated the safety or efficacy of intravitreal use of ramucirumab in the treatment of VEGF-driven diseases.

To study the safety of intraocular ramucirumab, we initially conducted a cell viability test in ARPE- 19 . We found that ramucirumab did not cause a significant decrease in the viability of ARPE-19 cells when exposed to $250 \mu \mathrm{g} /$ well. But a concentration of $500 \mu \mathrm{g} /$ well caused changes in cell morphology and reduced cell viability, compared to the lower concentrations. Figure 2 demonstrates a decrease in cell viability without statistical significance.

Luthra et al. [14] studied the cell damage response to two different anti-VEGF drugs, bevacizumab and ranibizumab, and found that even with 5 times the clinically relevant concentration of these drugs, there were no differences in cell viability in ARPE-19 cells and rat neurosensory retina cells. However, Malik et al. [15] showed that mitochondrial toxicity in ARPE-19 cells could be caused by bevacizumab and ziv-aflibercept (intravenous solutions). Using a similar approach, Dias et al. [11] did not find any cytotoxic effect in human RPE cultured cells exposed to ziv-aflibercept. Regarding aflibercept, 


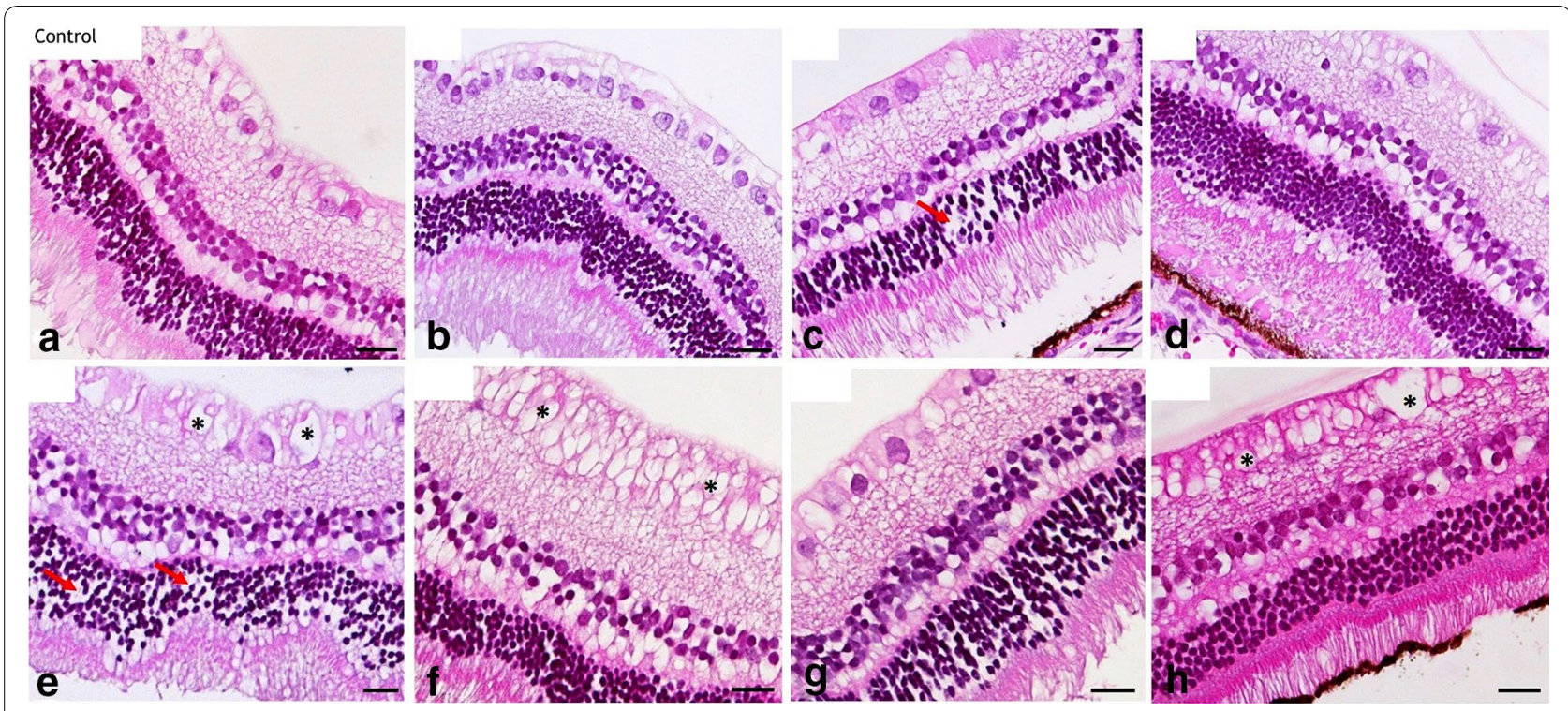

Fig. 5 Retinal findings by histology with hematoxylin and eosin staining seven days after intravitreal injection of ramucirumab. a control eye. b-d IVT injection of $250 \mathrm{\mu g}$ ramucirumab. e-h IVT injection of $500 \mu \mathrm{g}$ ramucirumab. Ganglion cells: focal areas of vacuolization $\left({ }^{*}\right)$. Inner plexiform and nuclear layers showing focal vacuolization. Outer plexiform layer: intact. Outer nuclear layer: artifactual findings (red arrows)

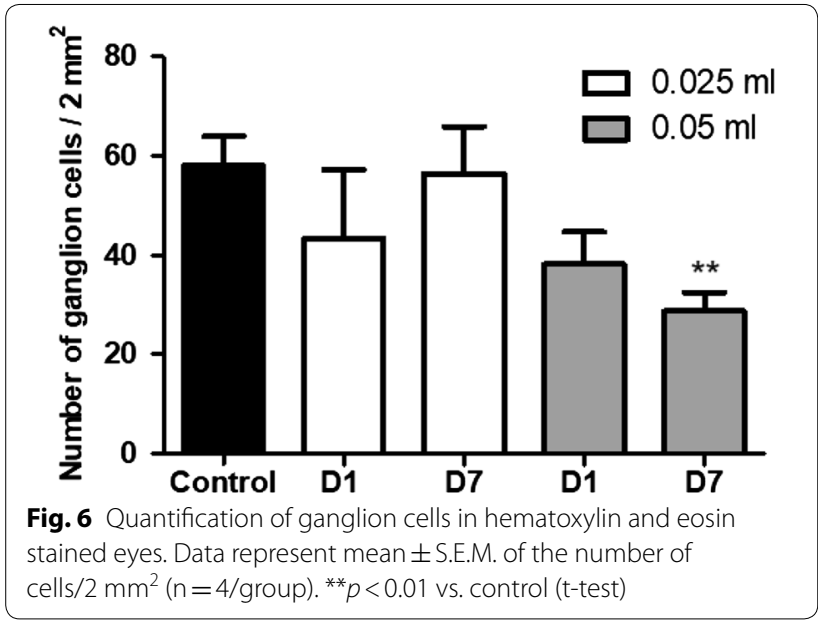

different authors reported no changes in ARPE-19 cell viability after different concentrations and times of aflibercept exposure [16, 17]. These findings are consistent with our results, which also demonstrated no decrease in cell viability compared with controls, when ramucirumab concentration was below $500 \mu \mathrm{g} /$ well.

For functional analysis and to minimize some of the known inter-eye variability of ERG assessment, we used an instrument capable of assessing both eyes at the same time $[18,19]$. In our analysis, there was no difference in the ERG when comparing baseline and follow-up of each eye (Table 1), which means the procedure did not cause any retinal functional impairments.
The osmolarity study was essential because the ramucirumab formulation is for intravenous use. Intravitreal injections of strong salt solutions may result in retinal detachment associated with vascular abnormalities [19]. However, recent studies did not see much impact of the $\mathrm{pH}$ or osmolarity of drugs in the vitreous cavity [20]. According to our data, osmolarity remained similar in all groups, suggesting that intraocular injections of 250 or $500 \mu \mathrm{g}$ of ramucirumab in rabbits do not alter either serum or the anterior chamber osmolarity.

All eyes were evaluated by H\&E staining. In eyes injected with $250 \mu \mathrm{g}$ ramucirumab, the morphology of the retina did not show any difference between druginjected and controls. The ultrastructural findings by TEM confirmed the findings of LM. Some degree of ganglion cell layer vacuolization occurred in all samples, including those from the control group, and the density of vacuoles decreased seven days after the injection compared with $24 \mathrm{~h}$ after the injection. This finding may indicate that the retina is able to recover in a few days after ramucirumab injection. To overcome the doubts raised by this finding, we counted the density of ganglion cells in the eyes studied. The quantification of ganglion cells showed a slight loss of cellular density in both groups at $24 \mathrm{~h}$. Seven days after the injection, the quantification of ganglion cells indicated a normal density in the $250 \mu \mathrm{g}$ group, while in the $500 \mu \mathrm{g}$ group, there was a statistically significant loss of cellular density. 


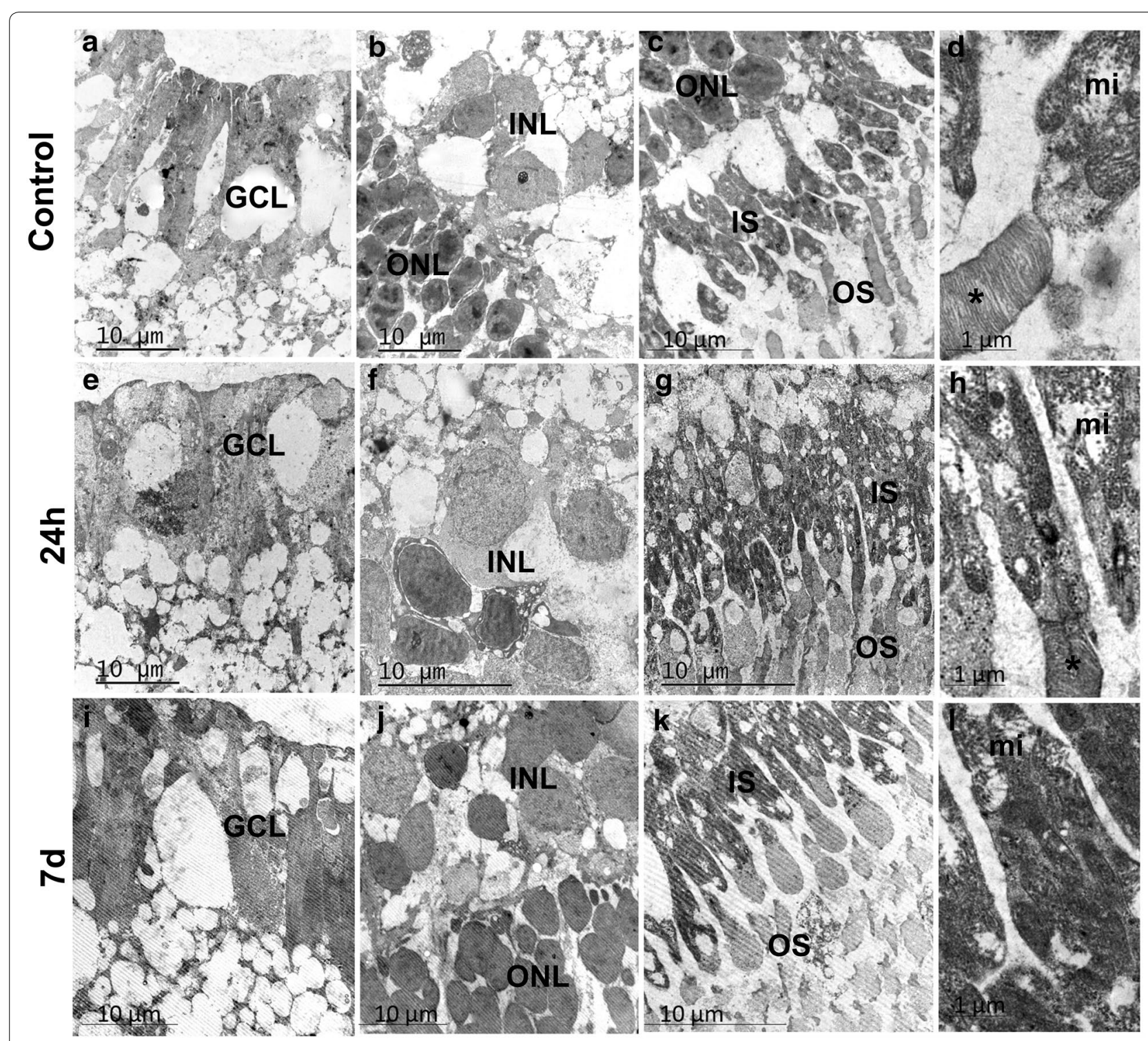

Fig. 7 Ultrastructural analysis of rabbit retinas treated with $500 \mu \mathrm{g}$ ramucirumab at $24 \mathrm{~h}$ and seven days. a-d Control. e-h $24 \mathrm{~h}$-treated retina. i-I 7 day-treated retina. All experimental conditions showed retinal layers with normal appearance, without signs of apoptosis. GCL ganglion cell layer, INL inner nuclear layer, ONL outer nuclear layer. In the inner photoreceptor segment (IS), notice the presence of mitochondria (Mi), while outer segment (OS) is characterized by the presence of disc membranes $\left(^{*}\right)$

\section{Conclusion}

Ramucirumab is an anti-VEGF drug used in the treatment of several types of adenocarcinomas, and its repurposing to treat neovascular eye disease is promising since it binds to VEGFR-2 and not only with its ligands. Our work presents evidence that this drug can be safely injected in the eyes of rabbits at a dose of $250 \mu \mathrm{g}$.

\section{Abbreviations}

AMD: Age-related macular degeneration; BSS: Balanced salt solution; ERG: Electroretinography; Fc: Fragment crystallizable; H\&E: Hematoxylin and eosin; IVT: Intravitreal; LM: Light microscopy; RPE: Retinal pigment epithelial; SD-OCT:
Spectral-domain optical coherence tomography; SEM: Standard error of mean; TEM: Transmission electron microscopy; VEGF: Vascular endothelial growth factor; VEGFR-2: Vascular endothelial growth factor receptor 2.

\section{Acknowledgements}

The authors thank Eduardo Amorim Novais, Vinicius Ferreira Kniggendorf, Ramon Antunes de Oliveira, Thais Mendes Tebaldi Barbosa, Felipe Muralha, João Rafael Dias de Oliveira, and Acácio Alves de Souza Lima for their technical assistance. Dr. A Levya (USA) helped with English editing of the manuscript.

\section{Authors' contributions}

JEMN, FP, RLN, NMT, and CDG performed the experiments. JEMN and FP wrote the paper with assistance from EBR. JEMN, FP, AGF, and SES analyzed the data. CHM, MEF, and EBR provided reagents, and conceived and directed the 
project. All authors had the opportunity to discuss the results and comment on the manuscript. All authors read and approved the final manuscript.

\section{Funding}

This work was supported by Fundação de Amparo à Pesquisa do Estado de São Paulo (FAPESP; São Paulo, Brazil), Conselho Nacional de Desenvolvimento Científico e Tecnológico (CNPq; Brasília, Brazil), and Pan-American Association of Ophthalmology/Pan-American Ophthalmological Foundation, Paul Kayser/ RRF Retina Research Foundation Global Award (PAAO/PAOF; Arlington, TX, USA).

\section{Availability of data and materials \\ All data generated or analyzed during this study are included in this published article.}

\section{Ethics approval and consent to participate}

Approval was obtained from the Institutional Animal Care and Use Committee (IACUC) of Universidade Federal de São Paulo prior to the initiation of the study, under the number 6610041117.

\section{Consent for publication}

Not applicable.

\section{Competing interests}

The authors declare that they have no competing interests.

\section{Author details}

${ }^{1}$ Departamento de Oftalmologia E Ciências Visuais, Escola Paulista de Medicina, Universidade Federal de São Paulo (UNIFESP), São Paulo, SP 04023-062, Brazil. ${ }^{2}$ Departamento de Biofísica, Escola Paulista de Medicina, Universidade Federal de São Paulo (UNIFESP), São Paulo, SP 04023-062, Brazil. ${ }^{3}$ Departamento de Morfologia E Genética, Escola Paulista de Medicina, Universidade Federal de São Paulo (UNIFESP), São Paulo, SP 04023-900, Brazil. ${ }^{4}$ Department of Ophthalmology, Saint Louis University Eye Institute (SLUEI), St. Louis, MO 63104, USA

Received: 14 May 2020 Accepted: 25 August 2020 Published online: 04 September 2020

\section{References}

1. Andreoli CM, Miller JW. Anti-vascular endothelial growth factor therapy for ocular neovascular disease. Curr Opin Ophthalmol. 2007:18:502.

2. Tugues S, Koch S, Gualandi L, Li X, Claesson-Welsh L. Vascular endothelial growth factors and receptors: Anti-angiogenic therapy in the treatment of cancer. Mol Aspects Med. 2011;32:88.

3. Senger DR, Davis GE. Angiogenesis. Cold Spring Harbor Perspect Biol. 2011;3:e005090.

4. Potgens AJG, Lubsen NH, van Altena MC, Vermeulen R, Bakker A, Schoenmakers JGG, et al. Covalent dimerization of vascular permeability factor/ vascular endothelial growth factor is essential for its biological activity. Evidence from Cys to Ser mutations. J Biol Chem. 1994;269:32879.

5. Shibuya M, Claesson-Welsh L. Signal transduction by VEGF receptors in regulation of angiogenesis and lymphangiogenesis. Exp Cell Res. 2006;312:549
6. Lu D, Shen J, Vil MD, Zhang H, Jimenez X, Bohlen P, et al. Tailoring in vitro selection for a picomolar affinity human antibody directed against vascular endothelial growth factor receptor 2 for enhanced neutralizing activity. J Biol Chem. 2003;278:43496.

7. Meyer $\mathrm{CH}$, Holz FG. Preclinical aspects of anti-VEGF agents for the treatment of wet AMD: ranibizumab and bevacizumab. Eye. 2011;25:661

8. Spratlin JL, Cohen RB, Eadens M, Gore L, Camidge DR, Diab S, et al. Phase I pharmacologic and biologic study of ramucirumab (imc-1121b), a fully human immunoglobulin G1 monoclonal antibody targeting the vascular endothelial growth factor receptor-2. J Clin Oncol. 2010;28:780.

9. Zhu Z, Hattori K, Zhang H, Jimenez X, Ludwig DL, Dias S, et al. Inhibition of human leukemia in an animal model with human antibodies directed against vascular endothelial growth factor receptor 2. Correlation between antibody affinity and biological activity. Leukemia. 2003;17:604.

10. Costa EF, Barros NMT, Coppini LP, Neves RL, Carmona AK, Penha FM, et al. Effects of light exposure, $\mathrm{pH}$, osmolarity, and solvent on the retinal pigment epithelial toxicity of vital dyes. Am J Ophthalmol. 2013;155:705.

11. Dias JRDO, Badaró E, Novais EA, Colicchio D, Chiarantin GMD, Matioli MM, et al. Preclinical investigations of intravitreal ziv-aflibercept. Ophthalmic Surgery Lasers Imaging Retina. 2014:45:577.

12. Diaz-Serrano A, Riesco-Martinez MC, Garcia-Carbonero R. The safety and efficacy of ramucirumab for the treatment of metastatic colorectal cancer. Exp Rev Anticancer Ther. 2016;16:585.

13. Fleetwood F, Güler R, Gordon E, Ståhl S, Claesson-Welsh L, Löfblom J. Novel affinity binders for neutralization of vascular endothelial growth factor (VEGF) signaling. Cell Mol Life Sci. 2016;73:1671.

14. Luthra S, Sharma A, Dong J, Neekhra A, Gramajo AL, Seigel GM, et al. Effect of bevacizumab (Avastin TM ) on mitochondrial function of in vitro retinal pigment epithelial, neurosensory retinal and microvascular endothelial cells. Indian J Ophthalmol. 2013;61:705.

15. Malik D, Tarek M, del Carpio JC, Ramirez C, Boyer D, Kenney MC, et al. Safety profiles of anti-VEGF drugs: Bevacizumab, ranibizumab, aflibercept and ziv-aflibercept on human retinal pigment epithelium cells in culture. Br J Ophthalmol. 2014;98:i11.

16. Schnichels S, Hagemann U, Januschowski K, Hofmann J, Bartz-Schmidt $\mathrm{KU}$, Szurman P, et al. Comparative toxicity and proliferation testing of aflibercept, bevacizumab and ranibizumab on different ocular cells. $\mathrm{Br}$ J Ophthalmol. 2013;97:917.

17. Ammar DA, Mandava N, Kahook MY. The effects of aflibercept on the viability and metabolism of ocular cells in vitro. Retina. 2013;33:1056.

18. Maturi RK, Bleau LA, Wilson DL. Electrophysiologic findings after intravitreal bevacizumab (Avastin) treatment. Retina. 2006:26:270.

19. Marmor MF, Martin $\sqcup$, Tharpe $S$. Osmotically induced retinal detachment in the rabbit and primate Electron microscopy of the pigment epithelium. Invest Ophthalmol Visual Sci. 1980;19:1016.

20. Sobolewska B, Heiduschka P, Bartz-Schmidt KU, Ziemssen F. pH of antiVEGF agents in the human vitreous: low impact of very different formulations. Int J Retina Vitreous. 2017;3:22.

\section{Publisher's Note}

Springer Nature remains neutral with regard to jurisdictional claims in published maps and institutional affiliations.

Ready to submit your research? Choose BMC and benefit from:

- fast, convenient online submission

- thorough peer review by experienced researchers in your field

- rapid publication on acceptance

- support for research data, including large and complex data types

- gold Open Access which fosters wider collaboration and increased citations

- maximum visibility for your research: over 100M website views per year

At BMC, research is always in progress.

Learn more biomedcentral.com/submissions 